\title{
EDITORIAL
}

\section{As perspectivas da psicologia escolar/ educacional}

Com base nesse tema, psicólogos, pesquisadores e muitos estudantes interessados na área reuniram-se em Salvador-BA, no mês de abril, para o VI Congresso de Psicologia Escolar e Educacional (VICONPE). O evento teve a participação de aproximadamente mil inscritos e os trabalhos apresentados foram atinentes a diferentes sub-temas a saber, Avaliação e medidas no contexto escolar; Desenvolvimento humano; Educação infantil; Educação informal; Ensino de psicologia; Ensino fundamental; Ensino médio; Ensino superior; Família; Formação do educador; Formação do psicólogo escolar/educacional; Fracasso escolar/evasão; Leitura/escrita; Necessidades especiais/inclusão; Orientação profissional; Pesquisa em psicologia escolar/educacional; Prevenção; Tecnologia educacional e Terceira idade.

Pudemos contar com o acolhimento carinhoso do povo baiano e, em especial, com o apoio irrestrito do corpo diretivo e dos docentes e alunos da Faculdade Ruy Barbosa, que sediou nosso evento. A Comissão Organizadora, coordenada pela Profa. Dra. Nádia Rocha, teve um papel preponderante para que o VICONPE pudesse acontecer nos padrões desejados. Foi uma oportunidade ímpar de agregarmos congressistas advindos da grande maioria dos estados brasileiros, o que reforçou nosso propósito de que cada um dos nossos congressos, que têm caráter nacional, ocorra em uma das diversas regiões do país para permitir uma participação mais ampla daqueles que se encontram fora do eixo Rio - São Paulo.

As atividades apresentadas, nos quatro dias de duração do evento, foram propostas por professores universitários, pós-graduandos e profissionais da área, que ofereceram uma extensa gama de trabalhos em forma de conferências, mesas-redondas, simpósios, cursos e workshops que demonstraram as características da produção científica na área, bem como, a diversidade de práticas profissionais. É importante ressaltar que as seções de comunicação oral e os painéis apresentados contribuíram, em muito, para que pudéssemos registrar e divulgar a amplitude de interesses e de abordagens presentes em nossa área. Duas novas modalidades, não existentes nos congressos anteriores - 'Depoimento' e 'Partilhando Experiências' foram ricas o suficiente para serem citadas positivamente na avaliação dos participantes, o que significa que vale a pena mantê-las e incrementálas nos próximos eventos a serem realizados.

O apoio de órgãos de fomento (CAPES, CNPq e FAPESB) e de outras instituições públicas (Universidade Federal de Bahia e Secretaria Municipal de Educação e Cultura de Salvador) e particulares (Casa do Psicólogo; Colégio Módulo; Pinheiro Viagens e Turismo) foi indispensável para a viabilização financeira do evento. Além disso, merece destaque especial o auxílio do Conselho Federal de Psicologia e os Conselhos Regionais de São Paulo (CRP-06) e da Bahia (CRP-03), o que nos mostra a importância da aproximação das entidades científicas com as entidades profissionais, ambas buscando o fortalecimento da psicologia como ciência e como profissão. Sem dúvida, a quantidade e qualidade dos trabalhos apresentados não seria a mesma sem a participação da Comissão Científica e dos avaliadores ad-hoc que dedicaram parte significativa do seu tempo na análise cuidadosa das propostas encaminhadas. 
Ainda com a preocupação de registrar o grande valor da divulgação das temáticas relevantes para os interessados na área de psicologia escolar e educacional queremos expressamente agradecer o apoio financeiro que esta revista passou a ter no ano de 2003 do Programa de Auxílio Editoração do CNPq, que viabilizou sua impressão e nos possibilitou garantir sua periodicidade. Esperamos que essa ajuda, somada ao nosso empenho de buscar sempre uma melhor qualidade para nossa revista se reflita no conteúdo e no alcance que os artigos aqui publicados possam ter, favorecendo o impacto que um periódico científico pretende alcançar na sua área de abrangência. Assim, estaremos de fato abrindo novas e amplas perspectivas para a área de Psicologia Escolar/Educacional.

Acácia Aparecida Angeli dos Santos

Editora 